Article

\title{
Behavioral Economics and Energy Consumption: Behavioral Data Analysis the Role of Attitudes and Beliefs on Household Electricity Consumption in Iran
}

\author{
Nima Norouzi, Maryam Fani *, Ehsan Hashemi Bahramani, Mohammad Hossein Hemmati, Zahra Bashash Jafara- \\ badi
}

How to cite this paper: Norouzi, N., Fani, M., Hashemi Bahramani, E. Hemmati, M. H., \& Bashash Jafarabadi, Z. (2021). Behavioral Economics and Energy consumption: Investigating the Role of Attitudes and Beliefs on Household Electricity Consumption in Iran. Journal of Artificial Intelligence and Big Data, 1(1).

Retrieved from

https://www.scipublications.com/journal/index.php/jaibd/article/view/54

Received: June 20, 2021 Accepted: July 22, 2021 Published: July 23, 2021

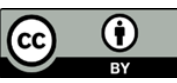

Copyright: (c) 2021 by the authors Submitted for possible open access publication under the terms and conditions of the Creative Commons Attribution (CC BY) license (http://creativecommons.org/licenses /by/4.0/).

\author{
Department of Energy Engineering and Physics, Amirkabir University of Technology (Tehran Polytechnic), \\ 424 Hafez Avenue, PO. Box 15875-4413, Tehran, Iran \\ *Correspondence: mfani@aut.ac.ir
}

\begin{abstract}
The average electricity consumption in Iranian households is higher than the world average. This can be due to price factors (such as cheap electricity in the country) and non-price factors (such as socio-demographic variables and psychological factors). In this study, non-price factors such as socio-demographic variables and psychological factors in the electricity consumption of urban households in Tehran were investigated. In this regard, using the theoretical foundations of behavioral economics and the psychology of planned behavior, this issue was analyzed. This study collected information on household electricity consumption behavior through a questionnaire and fieldwork from 2560 Tehran households. Results Using econometric techniques, linear regression was estimated, the dependent variable of which was electricity consumption (45 days in winter 2019) and its independent variables including socio-demographic variables (age, sex, number of household members, income) and The variables of the theory of planned behavior (attitude, mental norms and perceived behavioral control) showed that income and the number of household members have a significant and positive effect on electricity consumption, but gender has no significant effect. Of the psychological variables, only perceived behavioral control has a significant effect on electricity consumption. These results show that the consumer does not have a positive attitude towards saving, and mental and social norms do not encourage him to reduce electricity consumption, and they are not effective in consumption control. Finally, the study results were analyzed using behavioral biases that may cause attitudes and beliefs not to lead to action.
\end{abstract}

Keywords: Energy Demand; Demand Analysis; Behavioral Analysis; Electricity Market

\section{Introduction}

Energy is one of the main factors of production and complements other factors and inputs of production[1]. Among these, electrical energy is one of the most important forms of energy; Electricity plays an important role in enabling the production and supply of goods and services in various economic sectors[2]. This share is constantly increasing in proportion to the decrease in traditional production methods and replacing modern technologies[3]. On the other hand, the welfare and health of households have a deep connection with electricity consumption[4]. The availability and possibility of using electricity to meet the needs of households have gradually become a criterion for determining their level of well-being. Since a large part of cultural programs is broadcasted through video and audio media, electricity indirectly plays an important role in promoting the cultural level of society[5]. 
Despite the importance of electricity in the welfare of households, the growth of production, and economic development, the supply of electricity faces challenges such as financing, environmental pollution, and technical constraints such as transmission networks and unavailability[6]. This has made demand management and energy savings more important in recent decades. Therefore, economists have tried to identify solutions to reduce electricity consumption by identifying the factors affecting electricity consumption[7]. According to microeconomic studies, price policies can play an important role in controlling electricity consumption, but, given the role of this type of energy in the welfare of households and its market structure, the possibility of governments benefiting from these policies is limited[8]. Therefore, paying attention to non-price policies in managing electricity consumption is very important. Researchers are interested in identifying noncost factors affecting energy and electricity consumption[9].

Identification of non-price factors affecting the consumption of goods and services is available in the behavioral economics literature. Some of these factors are related to households' economic and social characteristics, such as age, gender, level of education, household income, and others related to individuals' psychological issues, including their beliefs and attitudes about electricity consumption. Many studies in this field have focused on attitudinal variables along with socio-demographic variables[10-14]. The amount of energy consumption is due to several factors, including social norms, learning, previous experiences in the family, school, individual differences, and finally, his beliefs and attitudes. It can be concluded that people's saving behavior is based on their thoughts, beliefs, and attitudes. Any change in sustainable behaviors requires fundamental changes in attitudes if people act on what they say and react according to their attitudes in most In countries where electricity is in the hands of the government, governments are reluctant to increase prices to control electricity consumption because the policy has many economic and social implications for governments because of its importance to household welfare and the production process[15]. The structure of the electricity market is competitive. The price of electricity is endogenous, and governments do not. They can set the price grammatically[16].

Trying to influence attitudes about energy saving will be an attractive strategy. Concepts such as belief, attitude, and behavior are strongly related [17]. It seems that to try to optimize household consumption, it is not possible to be satisfied only with technological advances (manufacturing low-consumption electrical appliances), and it is necessary to pay attention to household consumption habits and behavior. Management of electricity consumption and demand in the country is very important. However, considering that the price of household electricity in the country is determined by the government every year and usually, the real price of electricity is fixed or reduced, which encourages consumers who have consumed more of it. Therefore, identifying non-cost factors affecting household electricity consumption and policy-making based on it can be useful in managing electricity consumption in the country[18-22]. The present study examines the variables of the theory of planned behavior along with socio-demographic variables and in parallel with several behavioral biases (derived from the knowledge of behavioral economics and its effect on electricity consumption) to better understand the consumption behavior of electricity subscribers a Tehrani pays. Because the data collection in this study was through a questionnaire and in a limited period (so that the price of electricity has not changed), the price variable has been excluded[23, 24].

This article is organized into several sections. First, in the form of theoretical foundations, we give a brief description of behavioral economics and the theory of planned behavior, and then, the second part is devoted to a review of empirical studies. In the third part, the method used is explained, and the descriptive statistics of the respondents to the 
questionnaire are presented, and the variables used in the model are explained, and after estimating the model, the model results will be analyzed. In this section, 133 behavioral biases will be applied, and finally, conclusions, conclusions, and policy recommendations will be presented.

\section{Materials and Methods}

Identifying the factors affecting the consumption and demand of goods and services is one of the main goals of economics. In this regard, the neoclassical method and framework in economics provide a coherent and consistent theoretical body that provides accurate and concise behavioral models to explain, explain and predict human behavior. These models, accompanied by many auxiliary hypotheses, are used to analyze a wide range of phenomena, and their quality predictions are often consistent with people's feelings about many phenomena. For example, according to the law of demand, which is one of the main findings of this framework, under certain assumptions, consumers buy less when the price is higher and buy more when their income is higher[23-35].

The neoclassical framework includes but is not limited to consistent preferences, expected mental desirability, the Bayesian rule for updating probabilities, exponential temporalization, and unlimited cognitive abilities[1, 36-42]. Neoclassical economics is also based on problem-solving methods of optimization and equilibrium. However, although the neoclassical framework can break away from many of its classical assumptions, these generalizations have rarely occurred in reality and have not provided fundamental new insights even when these changes have been taken into account. Therefore, although this approach has been theoretically strong and coherent, experimental studies have not been very successful[13]. Over the past few decades, empirical, laboratory, and neuroscience evidence has raised serious concerns about neoclassical models' main assumptions and predictions. These observations were accompanied by advances in theoretical modeling that derived their insights and ideas from psychology, biology, anthropology, and sociology and were presented in behavioral economics. These models have achieved more experimental success compared to neoclassical models [14]. These models have been able to identify, model, and test the factors influencing human decisions to a large extent and have taken essential steps in identifying non-price factors affecting human behavior[24].

Behavioral economics has emerged as one of the relatively new branches of economics to improve economic knowledge and bring economic models closer to external realities and has gained considerable importance over the past few decades[25]. Researchers consider behavioral economics a reaction to conventional economics' weaknesses and shortcomings [17]. The core of behavioral economics theories is based on the psychological view derived from economics and psychology. In general, behavioral economists in various sub-disciplines seek to enrich and develop conventional theories of economics to construct better theories, concepts, and models for economic decision-making. None of the behavioral economists intends to deny the important successes of the current economy but rather to promote economic theory to create a more complete and realistic view of economic behavior [25,43].

Consumer behavior is very complex and rarely follows the rational decision-making theories of economics. When people decide what product to buy or what service to choose, they often think they have made a smart decision and are moving in a direction that they think is more logical and in line with their values and intentions. However, daily human life indicates that not all decisions are completely optimal[26]. Usually, real human behavior deviates from rational decision patterns, and in these decisions, the objective weights of costs and benefits are $100 \%$ reliable and indicate the optimal economic rate. For example, although many people still rely heavily on non-renewable energy sources, while 
acknowledging that they are extravagant and evaluating everything from an economic perspective, they do not care much about wasting energy. However, the important and hopeful point from the perspective of behavioral sciences is that even for this type of consumer, it is possible to put them on a sustainable path through awareness-raising methods, education processes, creating significant and obvious motivations[27]. Hoping to achieve lasting behaviors after an (albeit) long period. It is clear that sometimes people's words and actions are different; In many domains of human behavior, we see the gaps of knowledge-action, value-action, attitude-action, and (or) the gap of intention-action. For example, people may be aware of intrinsic values and have a positive attitude toward an issue or a real intention to act in certain desirable social activities, but most do not lead to actual behaviors[44-48]. One area in which these disconnections are evident is home energy consumption. Many people express their concerns about climate change and the importance of saving energy, but certainly, many of these concerns have not yet been addressed[28].

Perhaps campaigns and media campaigns with rational educational programs to promote pro-environmental attitudes and knowledge (by disseminating simple information) encourage households to save energy often fail to create the desired behavior. In this regard, it is generally clear that people's behavior is not dependent on their environmental concerns. These concerns are expressed in the form of a simple commitment (without proper action) because they are often looking for material attractions and external rewards. In this regard, researchers in psychology and behavioral economics have tried to answer this question by expressing valid theories. Next, we discuss the theory of programmed behavior proposed by references[29, 30].

\subsection{Theory of planned behavior}

Before addressing the Theory of Planned Behavior (TPB), it is necessary to explain the Theory of Reasoning Action (TRA) proposed by Fishbein and Ajgen in 1975 because the Theory of Planned Behavior is a complementary approach to this theory.

The source of development and growth is the theory of reasoning and the theory of planned behavior of social psychology. Social science psychologists try to explain how and why individuals' attitudes and beliefs affect their behavior. The study of the effect of attitude on behavior began in 1872 by Charles Darwin. Darwin defined attitude as the physical state of a feeling. In 1882, Psychologists began to develop theories to explain how attitudes affect behavior. The results of these studies led to the emergence of many new theories about the role of attitude in behavior between 1918 and 1925. Thomas and Zennik were the first psychologists to state that attitude is a person's mental process determining a person's actual and potential responses. In this regard, psychologists began to examine attitudes as a predictor of behavior[27]. Following these advances, Ajgen and Fishbein sought to find ways to predict their behavior and outcome. They assumed that people are usually perfectly rational people. They systematically use the information available to them and consider all aspects of the behavior before deciding whether or not to do it. After reviewing all their studies, they proposed a theory that could make their behavior and attitudes understandable and predictable. This theory was called the theory of rational action[29, 49].

The theory of rational action theory was developed in 1967. This theory represents models for predicting the intention to perform a particular behavior and a person's decisions about whether or not to perform the desired behavior. This theory can be used in various populations and behaviors. This theory can be used to justify any behavior that a person can control[30]. 
This theory is based on the assumption that people act rationally. They gather and evaluate all available information about the target behavior regularly, consider the effect and result of the actions, and then decide based on their reasoning whether or not to do the action [31]. In this model, it is assumed that behavioral intention is the direct determinant of behavior, and other factors that affect behavior are indirect. From the perspective of the designers of this theory, the most important factor determining a person's behavior is his behavioral intention. Behavioral intention indicates the intensity of an individual's will to perform the intended behavior or the degree to which it is likely to be performed [32]. The relationship between behavioral intention and behavior indicates that people tend to engage in behaviors that they intend to perform.

From the perspective of Fishbein and Ajjen, behavioral intention depends on the person's attitude toward his behavior and mental norms. Therefore, behavior is always after the behavioral intention and connected to it. In other words, this theory assumes a causal relationship between attitudes and mental norms of the individual with the behavioral intention[33, 50-57].

Attitude is the evaluator's reactions or evaluations, for or against a situation, individual, or group, expressed in the form of feelings, beliefs, and even behavior. Attitude is related to one's beliefs about the consequences of that behavior. In other words, when a person believes that behavior will have valuable consequences for him, he will have a positive attitude towards it and vice versa. Attitude toward a behavior is determined by a person's belief in the outcome of the behavior and its evaluation. In other words, according to this theory, a person's attitude towards a subject is the result of the performance of one's beliefs about it and the evaluation of responses concerning these beliefs. Therefore, an individual's attitude toward a behavior is the product of attitude beliefs (the individual's mental probability that the goal behavior will lead to a consequence) in evaluating those consequences (explicit evaluative response to the outcome) [34, 58-62].

Mental norms result from normative beliefs in which the approval or rejection of the desired behavior by the reference people of the society is discussed. In other words, it refers to the social pressure perceived by the individual to do or not to do the target behavior. People often behave based on their perceptions of others (friends, family, co-workers, and people with whom they have a close relationship) behave[35]. In the theory of reasoning, the mental norm of the individual is the product of the multiplication of normative beliefs (expectations perceived by individuals or specific reference groups) in the individual motivation to perform the target behavior despite these expectations [17]. Figure 1 describes the process of formation of real behavior in the form of the theory of reasoning.

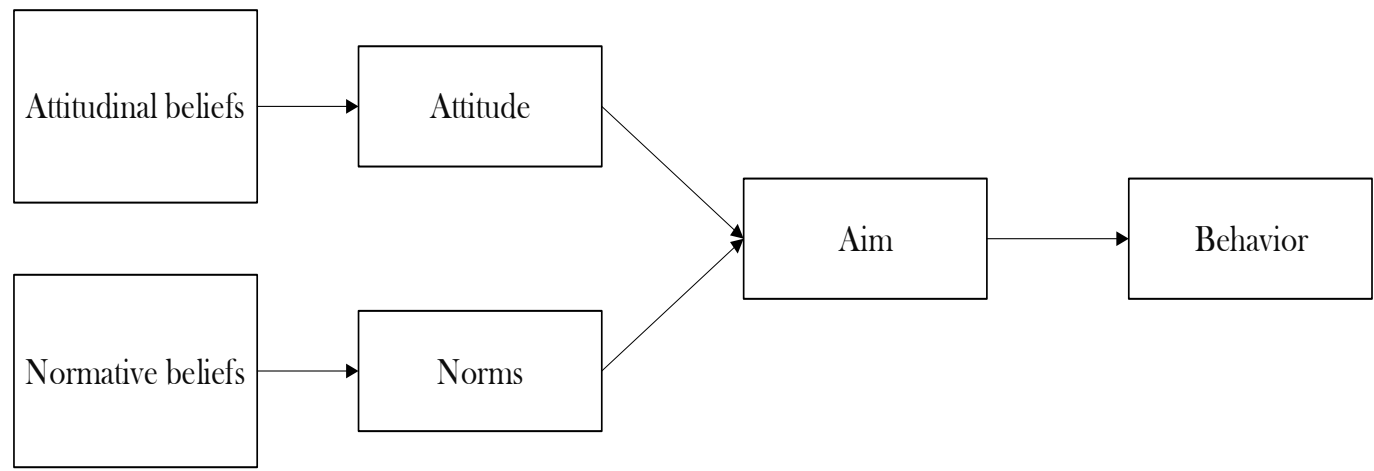

Figure 1. Theory of reasoning $[15,22,36]$ 
In the theory of reasoning, it is claimed that the behavior is exclusively under the control of the behavioral intention; If the behavior of the skills, resources, and opportunities that can be easily manually be found the need of which this case in the field of functional capabilities action theory argument under consideration has not been or is likely to be incomplete by this theory is predicted [22]. A researcher has developed the theory of reasoning practice by introducing the behavioral control factor perceived as the determinant of behavioral intention and behavior[23, 63-69]. This theory can try to explain behavior and change. This theory predicts the occurrence of a particular behavior; Provided that the person intends to do so. The theory of planned behavior reflects the internal and external constraints of the behavior [17]. According to this theory, the intent to perform a behavior is predicted by three perceived attitudes toward behavior, perceived mental norms, and behavioral control. A general rule, good posture, good abstract norms, and perceived behavioral control make it more likely that the individual intends to perform the behavior. The first two factors are described in the theory of reasoning behavior. In the following, we will describe the third factor influencing the real behavior of individuals.

The third factor that affects people's intention to perform a behavior or not to perform a behavior is perceived behavioral control. In the theory of planned behavior, perceived behavioral control is defined as an individual's assessment of whether a behavior is difficult or easy. Perceived behavioral control determines behavior when perceived behavioral control reflects individuals' actual control over the behavior in question. Several environmental and organizational factors can make a particular behavior easier or more difficult to perform. Perceived behavioral control is assumed to reflect a person's previous experience and anticipated barriers to performing a behavior. Perceived behavioral control is a degree of a person's sense of how much behavior is or is not under their voluntary control [23]. Perceived behavioral control, both directly and indirectly through behavioral intent, may affect actual behavior [70-77]. Perceived behavioral control consists of two parts: 1 . Control beliefs include internal control factors (information, skills, and individual abilities) and external control factors (opportunities, resources, and facilities) to perform the behavior [37]. 2. The perceived power is used to control each of these facilitators or deterrents. Figure 2 shows the performance process of the theory of planned behavior.

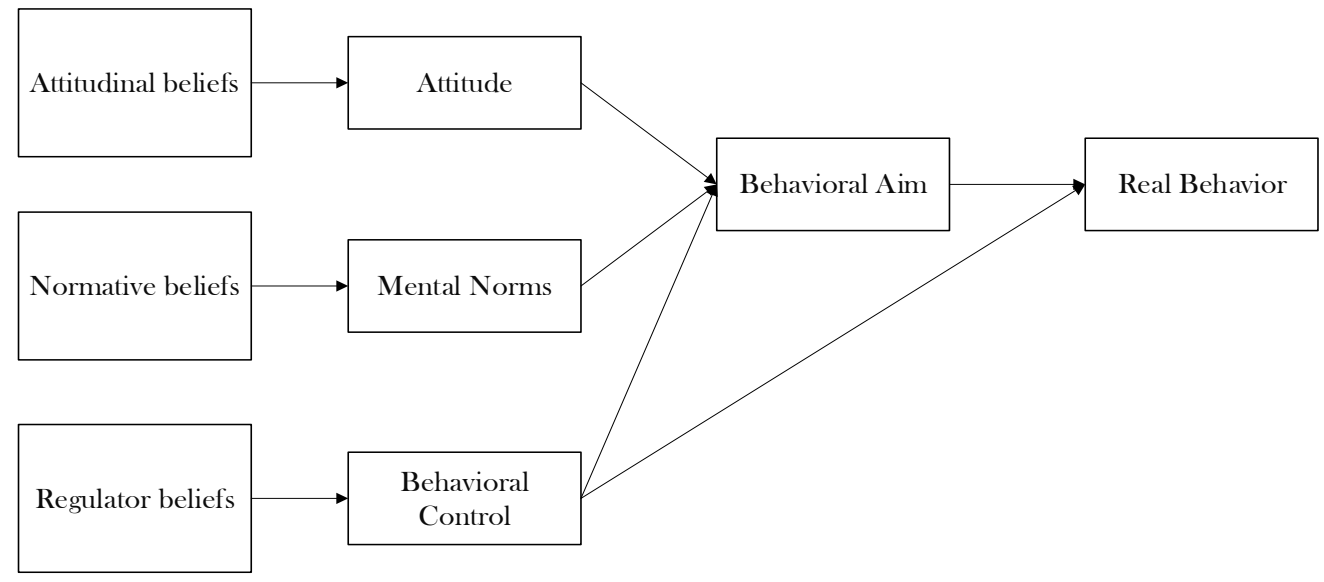

Figure 2. Theory of planned behavior

Based on the theory of planned behavior, behavioral beliefs and evaluation of results create a favorable or unfavorable attitude towards the individual's behavior. The result of normative beliefs and the motivation to fulfill the normative expectations of others are found in the mental norm, and control beliefs also determine the perceived behavioral 
control. In general, attitudes about behavior, mental norms, and perceived behavioral control lead to intentional behavior[78, 79].

The TPB variables, psychological (attitudes, subjective norms, and perceived behavioral control) indirectly, such as social variables - population individuals behavior (power) effectively assumes and assumed that these psychological variables between socio-demographic And mediate behavior. Experimental studies in TPB in the range of energy-dependent behaviors are very high (for further study, see [11, 19]). TPB assuming that people as program Ryzyshdh, logical decisions in the sense that usually interests their own to pursue a behavior motivation are (for example, in the sense that environmental behaviors friendly to them agonizing and interest in it do not, or Social approval is more important to them and ultimately results in behavior). So the theory of planned behavior variables Ryzyshdh may be a good explanation for relatively costly behaviors is similar to a used car or the use of energy factors that may cause behavioral intent not to lead to action can be found in behavioral economics. In behavioral economics studies, several cases have been mentioned that are known as the causes and factors of violating the assumptions of rationality, called behavioral or cognitive errors. Here are some of the most important mistakes that play an important role in deciding household energy consumption[23].

Bureau of maintaining the status quo and delaying decision-making: This erroneous expression states that although in some cases changes in decision-making and choices increase the well-being of individuals, they tend to maintain the status quo and avoid change. This error usually occurs when a decision requires complex information.

Availability bias: It is a rule of thumb or a mental shortcut by which people estimate the probability of an outcome based on the prevalence or prevalence in their lives and experiences. Accordingly, people estimate the probability of easily remembered events to be higher than those not easily recalled.

Risk aversion: Specifically, people focus more on risks, costs, and losses when making decisions in uncertain situations.

Time and place discounts: People often do not pay attention to discounting their costs and benefits over time. This error is more common, especially when the initial costs are high, but the benefits take a long time to achieve (replacing high-consumption electrical appliances to reap the benefits of reducing electricity costs)[80].

\subsection{Literature Review}

A study answered that with what variables from the theories of psychology and socio-demographic variables (income, household size, age) can explain the household's energy consumption and the intention to reduce it. This study found that energy consumption seems to be strongly dependent on socio-demographic variables, while attitudinal and self-excellence variables are also very important. They also found that the intention to reduce household energy consumption directly and positively to understand control behaviors depends on protecting the environment and its attitude[33].

With the help of critical insights into behavioral and psychological economics, Researchers clarified the key role of cognitive underpinnings and motivational factors that may answer why it is difficult and complex to predict household energy-dependent behaviors. Are these behaviors the source of values or material attractions? They found that psychological variables could make households more responsible for public intervention policies to protect an environment that has few sponsors and could also, in parallel, design cost-effective and comprehensive behavioral solutions to encourage cost-effective consumers. Seek non-renewable energy[34]. 
Research has also been done by designing experimental domains to apply non-price stimuli and compare economic and non-economic stimuli to reduce household energy consumption.

Reactions have been performed, and below are some examples of this type of research:

A study addresses the relationship between social norms and energy conservation. With the help of Opower, he designed and conducted an experiment in which he wrote a letter to 600,000 households participating in the experiment with their electricity bills, including a report and information on average sample consumption and household consumption, and a comparison with other neighbors and suggestions for Increased energy savings were given; They found that the effect of these non-price interventions was very significant and equal to a short period of price increase between 11 and 20 percent. They also examined the welfare effects of this type of intervention[23].

In an article, researchers raised awareness about nonlinear pricing to make this type of pricing more effective for households. They designed an experiment in which participating households were given their electricity bills in more detail. They drew up a price chart for each household and showed them which part of the chart they were in. The household was also given suggestions on managing consumption and what strategies should be placed at the bottom of the chart. They found that providing consistent and active information to consumers was very effective in maximizing the effectiveness of dynamic pricing[12].

In a study on the persistence of the effects of moral incentives compared to economic incentives in a field study involving 675 sample households, some of which were exposed to moral incentives and some of which were exposed to dynamic prices higher than the original price. (Economic motivation) to study the effects of these interventions. These interventions were performed during selected days (with the lowest and highest temperatures) from the two seasons of winter and summer with an interval of three months (to identify the effect of persistence) and during peak hours. After installing smart meters, they received consumer information every 30 minutes. The researchers found that moral motivation had significant short-term effects that diminished rapidly after repeated interventions. In contrast, economic incentives produced more long-term and lasting effects that result from the formation of habits after the final intervention[38].

\subsection{Modeling}

In this study, to quantify the qualitative variables, the theory of programmed behavior is based on the 5-point Likert scale method, in which one means "Strongly Agre" and five means "Strongly disagree[81-86]."

Likert scale is a psychometric scale in the research questionnaire used in this way between the scale (of the collective response to the questionnaires obtained), and there is a distinct method of scoring. In this scale or spectrum, the researcher considers the phrase (phrase) at the participants' disposal according to the subject matter of the individual research. The answers are categorized into several options that are categorized into five levels of answer ( 1 "strongly agree" to 5 "strongly disagree"), then no matter what. The numerical sum of these values gives the score on this scale, which indicates the tendency of the respondents; therefore, on this scale, the scale of the total score is discussed. Descriptive statistical techniques will also be used to analyze the scores obtained from the Likert spectrum[87].

\subsubsection{Data and sample}

To collect information, a questionnaire consisting of 3 parts was prepared and compiled. The first part is the questions related to socio-demographic variables and the cost 
of the electricity bill of the individual's last period. The second part contains questions of the theory of planned behavior, and the last part contains questions about the personal experiences of individuals about electricity consumption (according to the behavioral biases of the research)[88]. Thus, four questions were designed according to the concept of each bias. Three thousand questionnaires were distributed using statistical equations and a 95\% confidence level, which can be a good example of all Tehran electricity subscribers. Among these, 2560 questionnaires were approved and reviewed. Descriptive statistics for the sample are presented in Table 1.

Table 1. Descriptive statistics (social-demographic variables)

\begin{tabular}{ccccc}
\hline Questionnaires & Total & Valid & & \\
\hline value & 3000 & 2560 & & \\
Income Decile & I, II & III, IV, V & VI, VII, VIII & IX, X \\
Share & $\% 36.72$ & $\% 28.10$ & $\% 17.18$ & $\% 17.96$ \\
Gender & Male & Female & & \\
Share & $\% 39.6$ & $\% 60.4$ & & \\
Household Mem- & Min & Max & Std. Dev & \\
ber & 1 & 10 & $3.67(1.44)$ \\
value & Min & Max & Std. Dev \\
Age & 17 & 65 & $33.21(9.7)$ \\
value & Min & Max & Std. Dev & \\
Electricity Con- & 80 & 700 & 284.86 (98.74) & \\
sumption & & &
\end{tabular}

\subsubsection{Variables of the theory of planned behavior}

Attitudes 1, 5 The factors used to measure respondents attitudes toward the protection of electrical energy protection are as follows[90-96]:

"Energy saving is very painful."

"Energy protection means: I have to live with less welfare."

"If I reduce my energy consumption, my quality of life will decrease."

"Energy conservation is not very pleasant."

"Energy conservation reduces my freedom (meaning that if I take behaviors to reduce consumption)."

On average, households positively evaluated energy conservation Cronbach's alpha: 0.71, mean: 3.54, standard deviation: 0.78) (see Table 2).

Table 2. Attitudes of people towards electricity saving

\begin{tabular}{|c|c|c|c|}
\hline \multicolumn{4}{|c|}{ Factors } \\
\hline 1 & \multicolumn{3}{|c|}{ Saving energy is very painful. } \\
\hline 2 & \multicolumn{3}{|c|}{ Energy conservation means: I have to live in less prosperity. } \\
\hline 3 & \multicolumn{3}{|c|}{ If I reduce my energy consumption, my quality of life will decrease. } \\
\hline 4 & \multicolumn{3}{|c|}{ Energy conservation is not very enjoyable } \\
\hline 5 & \multicolumn{3}{|c|}{$\begin{array}{l}\text { Energy conservation reduces my freedom. (This means that if I take actions to re- } \\
\text { duce my energy consumption to conserve energy, I will not have the previous } \\
\text { freedom.) }\end{array}$} \\
\hline \multicolumn{4}{|c|}{ Factor Analysis Result } \\
\hline & Cronbach's alpha & Std. Dev & Mean \\
\hline & 0.71 & 0.78 & 3.54 \\
\hline
\end{tabular}


Abstract norms (SN), this variable is measured as follows: Respondents were asked who they consider responsible for energy conservation?Four baseline groups were considered to answer this question: "my friends", "government", "my family members" and "my neighbors" (Cronbach's alpha: 0.73, my average friends: 2.46 (standard deviation: 1.05), Average government: 1.72 (standard deviation: 0.9), average family members: 2.09 (standard deviation: 1.01), average neighbors: 2.24 (standard deviation: 1.07)). On average, households blamed all four groups, but the government, with the lowest average, is completely in agreement with the options, and this could indicate that people in Iranian society still do not want or can not believe that The people are ahead of the government in pursuing the right pattern of public consumption(see Table 3)[97-105].

Table 3. Abstract norms of individuals towards electricity saving

\begin{tabular}{llcc}
\hline & Factors & Std. Dev & Mean \\
\hline 1 & My Friends & 1.05 & 2.46 \\
2 & Government & 0.90 & 1.72 \\
3 & My Family Members & 1.01 & 2.09 \\
4 & My neighbors & 1.07 & 2.24 \\
\hline \multicolumn{3}{c}{ Factor Analysis Result } \\
\hline
\end{tabular}

Understanding Behavior Control (PBC) goes back to whether respondents feel that they can save electricity in their homes. "I know how I can save electricity," "I think 5\% reduction in my energy consumption is not hard-work", "I think I can really reduce 5\% of my energy consumption" "I can relatively easily reduce my energy consumption") On average, sample households, knowing the method of saving electricity, agreed with the notion that they felt they could be more economical and more efficient Cronbach's alpha: 0.72; Mean: 1.82 Standard deviations: 0.54)(see Table 4)[105-109].

Table 4. Understanding the control over the behavior of people in home electrical savings

\begin{tabular}{|c|c|c|c|}
\hline \multicolumn{4}{|c|}{ Factors } \\
\hline 1 & \multicolumn{3}{|c|}{ I know how to save on electricity. } \\
\hline 2 & \multicolumn{3}{|c|}{ I think a $5 \%$ reduction in my energy consumption will not be a difficult task. } \\
\hline 3 & \multicolumn{3}{|c|}{ I think I can reduce my energy consumption by $5 \%$. } \\
\hline 4 & \multicolumn{3}{|c|}{ I can reduce my energy consumption relatively easily. } \\
\hline \multicolumn{4}{|c|}{ Factor Analysis Result } \\
\hline & Cronbach's alpha & Std. Dev & Mean \\
\hline & 0.72 & 0.54 & 1.82 \\
\hline
\end{tabular}

\section{Results and Discussion}

In this section, using the information extracted from the questionnaire, an attempt is first to examine the factors affecting electricity consumption in the sample households from a statistical perspective using significant experimental modeling. Cross-sectional regression was used to study the statistical significance of each component of the theory of planned behavior (attitude, abstract norms, and perception of control over behavior) and socioeconomic variables on household electricity consumption in Tehran. The results of this regression are presented in Table 5. 
Table 5. Regression results for socio-demographic variables and variables of the theory of planned behavior (dependent variable, amount of electricity consumed in a period (Y) winter 2019, 2560 questionnaires)

\begin{tabular}{cccc}
\hline $\begin{array}{c}\text { Independent vari- } \\
\text { ables }\end{array}$ & Coefficient(sig.) & $\begin{array}{c}\text { Independent vari- } \\
\text { ables }\end{array}$ & Coefficient(sig.) \\
\hline Y-intercept & $33.07(0.68)$ & Attitude & $3.86(0.73)$ \\
Income & $18.82(0.02)$ & $\begin{array}{c}\text { Abstract norms } \\
\text { Understanding } \\
\text { control over behav- } \\
\text { ior }\end{array}$ & $-13.83(0.21)$ \\
Age & $0.59(0.52)$ & $\begin{array}{c}\text { io. } \\
\text { F-Statistic }\end{array}$ & $3.63(0.01)$ \\
Gender & $15.67(0.37)$ & R-Squared & 0.17 \\
Household size & $17.97(0.002)$ & & \\
\hline
\end{tabular}

Because cross-sectional data were used in this study, variance heterogeneity tests were used to evaluate the fit, and the results of Pagan and White tests are shown in Table 6.

Table 6. White and Pagan, and Harvey test results

\begin{tabular}{cc}
\hline Test & Result \\
\hline White & $0.58(0.96)$ \\
Pagan & $1.32(0.24)$ \\
Harvey & $1.18(0.31)$ \\
\hline
\end{tabular}

According to the table above, the assumption of variance heterogeneity has been rejected. According to Table 5, the calculated regression is significant in general. As expected the variables of income and household size are significant. Their sign is as expected (considering that these variables are also considered control variables, the significance of these two variables can be another sign of the correctness of the research regression. According to the table, in exchange for one million tomans in household income, approximately 18.87 $\mathrm{kWh}$ will be added to household electricity consumption. For everyone, an increase in the number of household members during $17.97 \mathrm{kWh}$ of electricity consumption is increased. The variables of planned behavioral theory show that only the variable of perception of control over behavior has become significant. But the remarkable thing is the positive relationship between the perceived behavioral control variable and power consumption, contrary to this study's expectation. To what extent does the individual have control and will over whether or not to perform a behavior? It was expected that if a person understood the energy-saving method, it would be more economical, and PBC would negatively affect energy consumption. As mentioned in the introduction to the statistical summary of Iranian household electricity consumption (and that we consume more than the global average), the positive relationship between $\mathrm{PBC}$ and electricity consumption can signify that this feeling is false in typical people. Saving is known to be a deterrent to learning, and this in itself can confirm the ineffectiveness of advertising messages and incentives to reduce consumption and save electricity.

But concerning the non-significance of the variables of attitudes and mental norms, one of the reasons for this is the gap between individuals' attitudes and mental norms and their actions in electricity saving. As explained earlier, people may have a positive attitude towards saving electricity, but they do not have to follow the training tips to reduce their electricity consumption, rooted in each person's mental framework and value system. 
These value systems have been created since childhood and throughout the years of life. Influencing this system and changing and directing one's behavior is very difficult and complex. It is important to know when and with what quality and scientific basis the educational policies in this field have started.

\subsection{Behavioral bias analysis}

Behavioral factors may cause people to make mistakes and bias in decision-making and action and do not behave according to beliefs through a questionnaire, the results of which are presented below.

Maintaining the status quo and delaying decision-making: To assess whether households suffer from this type of behavioral bias, the following questions were asked in the form of a questionnaire: "Never adjusted the initial settings of electrical appliances (to reduce "I have not changed its power consumption," "I do not read my electrical appliance manual at all (to reduce its energy consumption) because I believe that its initial settings are at its best," "Changing the settings of electrical appliances is difficult, and it's complicated, "Even if I know that one of my appliances (like the refrigerator-freezer) has improper settings, which leads to increased power consumption, I still do not try to change the setting") on average, respondents were not neutral about this bias Cronbach's alpha: 0.85 Mean: 3.26 Standard deviation: 0.81 ). This bias is evident in their behavior (although not severe); this claim is that the answers to these questions average between 3 to 4 , which shows the level of opposition of respondents to this bias. Therefore, it can be concluded that this bias affects electricity consumption, and appropriate behavioral interventions should be pursued to reduce bias, maintain the status quo and delay the decision on electricity consumption. For example, encouraging households to consider the basic assumptions of electronic devices, such as turning off the hot water system of dishwashers or washing machines or selecting short-term modes of wash cycles, can be effective (for further study of cognitive motivations and theories) that refer to studies in the literature to improve daily routines[38-40].

Availability bias: According to the questionnaire questions, "I do not pay attention to it due to the complexity of determining the price of electricity," "I never check all the contents of the electricity bill (due to its complexity," "How" "Electricity pricing is not important to me, and I do not try to understand it." "I never pay attention to the amount of electricity consumption because these numbers are vague and incomprehensible to me") Respondents were neutral about this bias.(Cronbach's alpha: 0.85 Mean: 3.34 Standard deviation: 0.97) And this may have been due to the high negative load of the questionnaire questions. Because the basis of this bias is new and recent information, in designing educational messages (to control this bias), it is necessary to use interconnected information which has a greater emotional load and is so-called vivid and more impressive. To stay longer in the individual's memory. Repeated repetition of this information can also be helpful. Dissemination of this type of information thematically in the media can make electricity-saving a social norm, and audio-visual reminders can prompt consumers to react promptly. Schultz suggests that people can be attracted to a particular activity through simple, easy, repetitive, and hassle-free incentives because people are more likely to be influenced by simple, finger-pointing information aligned with the results of other papers[41, 42].

Risk and Loss Avoidance: Four questions were designed for this section as well, "I do not trust them" "If I buy a new electrical appliance (because it consumes less electricity), I will pay attention to the scope and duration of its after-sales service, because I have doubts about its efficiency," the speed and quality of after-sales service for new electrical appliances with low power consumption are very important to $\mathrm{m}$ " Ease and convenience 
of working with new electrical appliances that consume low power are very important" which is more than standard, so this part of the questionnaire questions was not reliable.

The temporal and spatial discount bias, according to the questions in the questionnaire, "I am now willing to incur a cost due to the replacement of my high-consumption electrical appliances (such as refrigerators and freezers) in the hope that in the future by reducing electricity costs"I'll do it if I've justified, that replacing my high - end appliances (like refrigerators and freezers) will reduce my electricity bills in the future," "If there are training programs, Where it accurately teaches the benefits of replacing high-end appliances that are long-lasting, I encourage encouragement to replace such appliances," "If different solutions at different costs to reduce electricity consumption (and to "If there is a reduction in future costs, I will be more encouraged to spend in this case") Respondents have, on average, agreed to control and counter this bias, indicating that they have this bias in consumer behavior self-affirm. (Cronbach's alpha: 0.79 Mean: 2.05 standard deviation: 0.6).

One of the reasons for this bias in electricity consumption is the high initial investment costs in energy-efficient goods, more efficiency, and savings; While its benefits and benefits are delayed, it results gradually and over time[17, 19]. In the educational messages given to customers, one of the considerations should be to draw the long-term benefits of energy conservation. Studies suggest that various factors may reduce time discounts and encourage individuals to commit and patient in achieving their benefits [13].

\section{Conclusions}

In this article, an attempt was made to study the non-price variables affecting the electricity consumption of households in Tehran. For this purpose, behavioral economics and the theory of planned behavior from psychology were used. Then, using the theoretical literature related to behavioral biases that consumers may suffer from, household consumption behavior was explained. It was expected that socio-demographic variables would significantly affect household electricity consumption, and based on this, household income and dimension variables had a significant and positive effect on electricity consumption. Also, of the variables of the theory of planned behavior, which included attitude, mental norms, and perceived behavioral control, only perceived behavioral control had a significant effect on the power consumption of the study sample. Therefore, the findings of this study show that although, on average, people have a positive attitude towards saving electricity, this attitude has no significant effect on electricity consumption. Respondents also believe that firstly, there is no mental and social norm about reducing consumption, and secondly, social and mental norms that encourage people to reduce consumption do not significantly affect electricity consumption. But the only factor influencing significant consumer behavior is the control of perceived behavior, which shows that people do not find saving electricity difficult and difficult. Therefore, in short, it can be said that although people do not consider reducing electricity consumption difficult, because on the one hand they do not have a tendency and attitude in this direction and on the other hand energy protection and reducing electricity consumption is a mental and social norm in society. Therefore, in principle, there is no behavioral intention to reduce electricity consumption in individuals. Another finding of this study is that even though the sample household thought they were able to save and knew the method, this feeling did not ultimately lead to electricity savings and did not only help reduce electricity consumption but also helped members. An exemplary household comprises people who are oblivious to messages and teachings in this area and do not optimize their electricity consumption. Therefore, confirming previous studies, it can be said that although price variables play the most important role in electricity demand and consumption, psychological, 
social, and demographic variables are not ineffective and, in some cases, can play an important role in explaining changes in electricity demand. Therefore, policymakers should use a behavioral economics approach and psychological policy advice in formulating demand management policies (especially in cases where price instruments are limited for reasons such as government controls). Based on the findings of this study, policymakers need to correct and improve consumers' attitudes about the importance of electricity and energy and reduce its consumption. In this regard, policymakers must first identify why people do not tend to reduce energy consumption. In this study, some behavioral biases that may play a role in people's attitudes toward energy consumption were raised, and their role was confirmed; Biases such as availability, maintaining status quo and delaying decision making, avoidance, and time discounts. Policymakers should also strive to promote the protection of energy resources as a social norm in society and encourage energy consumers to study how to use electrical appliances and teach them how to use the equipment properly.

Supplementary Materials: "The data cannot be uploaded online, but a part can be available due to an official request from the corresponding author."

Author Contributions: “Conceptualization, NN, and MF; methodology, ZB; software, MH; validation, $\mathrm{NN}, \mathrm{MF}$, and $\mathrm{ZB}$; formal analysis, $\mathrm{NN}$; investigation, MF; resources, $\mathrm{MH}$; data curation, $\mathrm{EH}$; writing - original draft preparation, $\mathrm{NN}$; writing - review and editing, $\mathrm{MH}$; visualization, $\mathrm{MF}$; supervision, NN; project administration, $\mathrm{MH}$; All authors have read and agreed to the published version of the manuscript."

Funding: "This research received no external funding."

Data Availability Statement: "The data cannot be uploaded online, but a part can be available due to an official request from the corresponding author."

Acknowledgments: “Authors thank supports of the Iranian grid control organization(Tavanir) and Energy ministry for their kind support."

Conflicts of Interest: “The authors declare no conflict of interest.”

\section{References}

[1] Norouzi N . An Overview on the renewable hydrogen market. International Journal of Energy Studies. 2021, 6(1), 67-94.

[2] Ashoogh, M; Aghamolaei, T.; Ghanbarnejad, A.; Tajvar, A.; Utilizing the theory of planned behavior to Prediction the safety driving behaviors in truck drivers in Bandar Abbas 1392. Iranian Journal of Health Education and Health Promotion. 2013, 1(3), 5-14.

[3] Poulter, D.R.; Chapman, P.; Bibby, P.A.; Clarke, D.D.; Crundall, D. An application of the theory of planned behaviour to truck driving behaviour and compliance with regulations. Accident Analysis \& Prevention. 2008, 40(6), 2058-64.

[4] Siebert, L.C.; Sbicca, A.; Aoki, A.R.; Lambert-Torres, G. A Behavioral Economics Approach to Residential Electricity Consumption. Energies 2017, 10, 768. https://doi.org/10.3390/en10060768

[5] Walczak, D.; Dziawgo, L.; Dziawgo, D.; Buszko, M.; Pawłowski, J.; Żołądkiewicz-Kuzioła, A.; Krupa, D. Attitudes and Behaviors Regarding Environmental Protection in the Financial Decisions of Individual Consumers. Energies 2021, 14, 1934. https://doi.org/10.3390/en14071934

[6] Graczyk, A.M. Households Behaviour towards Sustainable Energy Management in Poland - The Homo Energeticus Concept as a New Behaviour Pattern in Sustainable Economics. Energies 2021, 14, 3142. https://doi.org/10.3390/en14113142.

[7] Neale, A. Zrównowazona konsumpcja. 'Zr' ódła koncepcji i jej zastosowania. Pr. Geogr. 2015, 141, 141-158.

[8] Wilk, I. Sustainable Consumer as a Reference Segment for the Company's Market Activities. Zesz. Nauk. Uniw. Szczecin'skiego Probl. Zarza dzania Finans. Mark. 2015, 38, 183-192.

[9] Zalega, T. Sustainable Consumption in Consumer. Stud. Ekon. Zesz. Nauk. Uniw. Ekon. Katowicach 2019, 383, 82-107.

[10] Pineiro-Villaverde, G.; García-Álvarez, M.T. Sustainable consumption and production: Exploring the links with resources productivity in the EU-28. Sustainability 2020, $12,8760$.

[11] O'Rourke, D.; Lollo, N. Transforming Consumption: From Decoupling, to Behavior Change, to System Changes for Sustainable Consumption. Annu. Rev. Environ. Resour. 2015, 40, 233-259.

[12] Kryk, B. Konsumpcja zrównowazona a proekologiczne style zycia.' Stud. Proc. Polish Assoc. Knowl. Manag. 2011, 51, 206-218. 
[13] Micheletti, M. Political Virtue and Shopping; Palgrave Macmillan: New York, NY, USA, 2003.

[14] Bylok, F. Konsumpcja hedonistyczna a konsumpcja etyczna. Czy potrzebna jest społecznie odpowiedzialna konsumpcja? Stud. Pr. WNEiZ 2016, 43, 39-55.

[15] Carrigan, M.; Attalla, A. The myth of the ethical consumer-Do ethics matter in purchase behaviour? J. Consum. Mark. 2001, 18, 560-578.

[16] Toti, J.-F.; Moulins, J.-L. How to measure ethical consumption behaviors? Rev. Interdiscip. Manag. Homme Entrep. $2016,24,45$.

[17] Lorek, S.; Fuchs, D. Strong sustainable consumption governance-Precondition for a degrowth path? J. Clean. Prod. 2013, 38, 36-43.

[18] Matel, A. Przesłanki ekologizacji konsumpcji z perspektywy zachowan’ konsumenckich. Zarza dzanie. Teor. Prakt. 2016, 16, 5561.

[19] Kiełczewski, D. Wpływ ekologizacji konsumpcji na zmiany w zarza dzaniu organizacjami. Han. Wew. $2016,6,55-63$.

[20] Seyfang, G. The New Economics of Sustainable Consumption. Seeds of Change; Palgrave Macmillan: New York, NY, USA, 2011.

[21] Rumianowska, I. Ekokonsumpcja jako warunek efektywniejszego wykorzystania zasobów przyrodniczych a s'wiadomos' $\mathrm{c}^{\prime}$ i zachowania konsumentów polskich. Res. Pap. Wrocław Univ. Econ. 2013, 318, 364-375.

[22] Choi, S.; Feinberg, R.A. The LOHAS lifestyle and marketplace behavior: Establishing valid and reliable measurements. In Handbook of Engaged Sustainability; Springer International Publishing: Cham, Switzerland, 2018; Volume 2, pp. 1069-1086.

[23] Zhang, T.; Siebers, P.O.; Aickelin, U. A three-dimensional model of residential energy consumer archetypes for local energy policy design in the UK. Energy Policy 2012, 47, 102-110.

[24] Frankel, D.; Heck, S.; Tai, H. Using a Consumer Segmentation Approach to Make Energy Efficiency Gains in the Residential Market; McKinsey and Company: Chicago, IL, USA, 2013; pp. 1-9.

[25] Smart Energy Consumer Collaborative. Consumer Pulse and Marketing Segmentation Wave 7. 2019. Available online: https: //smartenergycc.org/consumer-pulse-and-market-segmentation-wave-7-report/ (accessed on 14 June 2021).

[26] Guthridge, G.S. Understanding Consumer Preferences in Energy Efficiency: Accenture End-CONSUMER Observatoryon Electricity Management; Accenture: Dublin, Ireland, 2010.

[27] Black, I.; Eiseman, D. Climate Change Behaviours - Segmentation Study; University of Stirling: Stirling, UK, 2019.

[28] Xu, S.; Chu, C.; Zhang, Y.; Ye, D.; Wang, Y.; Ju, M. Entangled stakeholder roles and perceptions of sustainable consumption: An evaluation of sustainable consumption practices in Tianjin, China. J. Environ. Manag. 2018, 223, 841-848.

[29] Falcone, P.M.; Lopolito, A.; Sica, E. Instrument mix for energy transition: A method for policy formulation. Technol. Forecast. Soc. Chang. 2019, 148, 119706.

[30] Falcone, P.M. Analysing stakeholders' perspectives towards a socio-technical change: The energy transition journey in Gela Municipality. AIMS Energy 2018, 6, 645-657.

[31] Albert, A.; Maasoumy, M. Predictive segmentation of energy consumers. Appl. Energy 2016, 177, 435-448.

[32] Tumbaz, M.N.M.; Mog ulkoç, H.T. Profiling energy efficiency tendency: A case for Turkish households. Energy Policy 2018, 119, 441-448.

[33] Sütterlin, B.; Brunner, T.A.; Siegrist, M. Who puts the most energy into energy conservation? A segmentation of energy consumers based on energy-related behavioral characteristics. Energy Policy 2011, 39, 8137-8152.

[34] Fjałkowski, K. Rola psychologii w ekonomiczej teorii zachowan' ludzkich Gary'ego S. Beckera. Ekonomia 2013, 4, 54-63.

[35] Jakob, M. Marginal costs and co-benefits of energy efficiency investments. The case of the Swiss residential sector. Energy Policy 2006, 34, 172-187.

[36] Knight, R.L.; Lutzenhiser, L.; Lutzenhiser, S. Why Comprehensive Residential Energy Efficiency Retrofits Are Undervalued. In Proceedings of the American Council for an Energy-Efficient Economy Summer Study Conference, London, 21-23 June 2006; pp. $1-10$.

[37] Witek, L. Typologia konsumentów na rynku produktów ekologicznych. Probl. Zarza dzania, Finans. Mark. 2014, 35, $209-218$.

[38] Poortinga, W.; Darnton, A. Segmenting for sustainability: The development of a sustainability segmentation model from a Welsh sample. J. Environ. Psychol. 2016, 45, 221-232.

[39] do Paço, A.; Raposo, M. “Green” segmentation: An application to the Portuguese consumer market. Mark. Intell. Plan. 2009, 27, 364-379.

[40] Department for Environment Food and Rural Affairs. A Framework for Pro-Environmental Behaviours; DEFRA (Department for Environment, Food and Rural Affairs): London, UK, 2008; p. 76.

[41] Wind, Y. Issues and advances in segmentation research. J. Mark. Res. 1978, 15, 317-337.

[42] Kotler, P.; Wong, V.; Saunders, J.; Armstrong, G. Principles of Marketing, 4th European ed.; Pearson Education Limited: Essex, UK, 2005.

[43] Tabi, A.; Hille, S.L.; Wüstenhagen, R. What makes people seal the green power deal? - Customer segmentation based on choice experiment in Germany. Ecol. Econ. 2014, 107, 206-215.

[44] Hille, S.L. The Myth of the Unscrupulous Energy User's Dilemma: Evidence from Switzerland. J. Consum. Policy 2016, 39, 327347.

[45] Lutzenhiser, L. Social and Behavioral Aspects of energy use. Annu. Rev. Energy Environ. 1993, 28, $247-289$.

[46] Straughan, R.D.; Roberts, J.A. Environmental segmentation alternatives: A look at green consumer behavior in the new millennium. J. Consum. Mark. 1999, 16, 558-575. 
[47] Frederiks, E.R.; Stenner, K.; Hobman, E.V. Household energy use: Applying behavioural economics to understand consumer decision-making and behaviour. Renew. Sustain. Energy Rev. 2015, 41, 1385-1394.

[48] Yang, Y.; Solgaard, H.S.; Haider, W. Value seeking, price sensitive, or green? Analyzing preference heterogeneity among residential energy consumers in Denmark. Energy Res. Soc. Sci. 2015, 6, 15-28.

[49] Axsen, J.; TyreeHageman, J.; Lentz, A. Lifestyle practices and pro-environmental technology. Ecol. Econ. 2012, 82, 64-74.

[50] Hayn, M.; Bertsch, V.; Fichtner, W. Electricity load profiles in Europe: The importance of household segmentation. Energy Res. Soc. Sci. 2014, 3, 30-45.

[51] Santin, O.G. Behavioural patterns and user profiles related to energy consumption for heating. Energy Build. 2011, 43, 26622672.

[52] Vicente, P.; Reis, E. Segmenting households according to recycling attitudes in a Portuguese urban area. Resour. Conserv. Recycl. 2007, 52, 1-12.

[53] Steg, L. Promoting household energy conservation. Energy Policy 2008, 36, 4449-4453.

[54] Sorrell, S.; Dimitropoulos, J.; Sommerville, M. Empirical estimates of the direct rebound effect: A review. Energy Policy 2009, 37, 1356-1371.

[55] Wiser, R.H. Using contingent valuation to explore willingness to pay for renewable energy: A comparison of collective and voluntary payment vehicles. Ecol. Econ. 2007, 62, 419-432.

[56] Kollmuss, A.; Agyeman, J. Mind the Gap: Why do people act environmentally and what are the barriers to pro-environmental behavior? Environ. Educ. Res. 2002, 8, 239-260.

[57] Jensen, J.O. Measuring consumption in households: Interpretations and strategies. Ecol. Econ. 2008, 68, 353-361. 52. Gupta, S.; Ogden, D.T. To buy or not to buy? A social dilemma perspective on green buying. J. Consum. Mark. 2009, $26,378-393$.

[58] Edelson, E.; Olsen, M. Potential Social, Institutional, and Environmental Impacts of Selected Energy-Conservation Measures in Two Washington Communities. [Seatle and Yakima]; Battelle Pacific Northwest Labs: Richland, WA, USA, 1980.

[59] Mirek, J. Kryteria segmentacji rynku. Zesz. Nauk. Akad. Ekon. Krakowie 2000, 543, 105-115.

[60] Kotchen, M.J.; Moore, M.R. Private provision of environmental public goods: Household participation in green-electricity programs. J. Environ. Econ. Manag. 2007, 53, 1-16.

[61] Ben, H.; Steemers, K. Household archetypes and behavioural patterns in UK domestic energy use. Energy Effic. 2018, 11, 761771.

[62] Darnton, A.; Verplanken, B.; White, P.; Whitmarsh, L. Habits, Routines and Sustainable Lifestyles: A Summary Report to the Department for Environment, Food and Rural Affairs; AD Research \& Analysis for Defra: London, UK, 2011.

[63] Breukers, S.; Mourik, R.; Heiskanen, E. Changing Energy Demand Behavior: Potential of Demand-Side Management. In Handbook of Sustainable Engineering; Kauffman, J., Lee, K.-M., Eds.; Springer: Dordrecht, The Netherlands, 2013 ; pp. 773-792.

[64] Waris, I.; Hameed, I. An empirical study of purchase intention of energy-efficient home appliances: The influence of knowledge of eco-labels and psychographic variables. Int. J. Energy Sect. Manag. 2020, 14, 1297-1314.

[65] Botetzagias, I.; Malesios, C.; Poulou, D. Electricity curtailment behaviors in Greek households: Different behaviors, different predictors. Energy Policy 2014, 69, 415-424.

[66] Michelsen, C.C.; Madlener, R. Motivational factors influencing the homeowners' decisions between residential heating systems: An empirical analysis for Germany. Energy Policy 2013, 57, 221-233.

[67] Diamantopoulos, A.; Schlegelmilch, B.B.; Sinkovics, R.R.; Bohlen, G.M. Can socio-demographics still play a role in profiling green consumers? A review of the evidence and an empirical investigation. J. Bus. Res. 2003, 56, 465-480.

[68] Abrahamse, W.; Steg, L. How do socio-demographic and psychological factors relate to households' direct and indirect energy use and savings? J. Econ. Psychol. 2009, 30, 711-720.

[69] Sardianou, E. Estimating energy conservation patterns of Greek households. Energy Policy 2007, 35, 3778-3791.

[70] Yang, S.; Shipworth, M.; Huebner, G. His, hers or both's? The role of male and female's attitudes in explaining their home energy use behaviours. Energy Build. 2015, 96, 140-148.

[71] Liu, X.; Wang, Q.; Wei, H.H.; Chi, H.L.; Ma, Y.; Jian, I.Y. Psychological and demographic factors affecting household energysaving intentions: A TPB-based study in northwest China. Sustainability 2020, 12, 836.

[72] Albert, A.; Rajagopal, R. Smart meter driven segmentation: What your consumption says about you. IEEE Trans. Power Syst. 2013, 28, 4019-4030.

[73] Gouveia, J.P.; Seixas, J. Unraveling electricity consumption profiles in households through clusters: Combining smart meters and door-to-door surveys. Energy Build. 2016, 116, 666-676.

[74] Wang, Z.; Zhang, B.; Yin, J.; Zhang, Y. Determinants and policy implications for household electricity-saving behaviour: Evidence from Beijing, China. Energy Policy 2011, 39, 3550-3557.

[75] Gamel, J.; Menrad, K.; Decker, T. Which factors influence retail investors' attitudes towards investments in renewable energies? Sustain. Prod. Consum. 2017, 12, 90-103.

[76] Chattopadhyay, S.; Hadush, T.; Healyd, S. Attitudes to Renewable Energy Technologies: A Survey of Irish Households. In Energy Challenges for the Next Decade, Proceedings of the 16th IAEE European Conference, Ljubljana, Slovenia, 25-28 August 2019; International Association for Energy Economics: Ljubljana, Slovenia, 2019.

[77] Bell, S.; Judson, E.; Bulkeley, H.; Powells, G.; Capova, K.A.; Lynch, D. Sociality and electricity in the United Kingdom: The influence of household dynamics on everyday consumption. Energy Res. Soc. Sci. 2015, 9, 98-106. 
[78] Pedersen, M. Segmenting residential customers: Energy and conservation behaviors. In Proceedings of the ACEEE Summer Study on Energy Efficiency in Buildings, Pacific Grove, CA, USA, 7-22 August 2008; pp. 229-241.

[79] Han, Q.; Nieuwenhijsen, I.; de Vries, B.; Blokhuis, E.; and Schaefer, W. Intervention strategy to stimulate energy-saving behavior of local residents. Energy Policy 2013, 52, 706-715.

[80] Boudet, H.S.; Flora, J.A.; Armel, K.C. Clustering household energy-saving behaviours by behavioural attribute. Energy Policy 2016, 92, 444-454.

[81] de Freitas, D.; Van Eeden, T.S.; Christie, L. A psychographic framework for determining south african consumers' green hotel decision formation: Augmenting the theory of planned behaviour. J. Consum. Sci. 2020, 5, 1-18.

[82] Timofeeva, T.S.; Serova, O.F.; Golub, O.V. Study of Psychographic Characteristics of Consumers of Credit Products. In Proceedings of the International Scientific Conference "Far East Con" (ISCFEC 2020), Vladivostok, Russia, 1-4 October 2019; Atlantis Press: Dordrecht, The Netherlands; Volume 128, pp. 720-725.

[83] Rai, R.; Dhar, P.; Jha, A. Impact of psychographic factors on energy consciousness. AIP Conf. Proc. 2020, $2273,020013$.

[84] Sanguinetti, A.; Karlin, B.; Ford, R. Understanding the path to smart home adoption: Segmenting and describing consumers across the innovation-decision process. Energy Res. Soc. Sci. 2018, 46, 274-283.

[85] Maréchal, K.; Holzemer, L. Unravelling the 'ingredients' of energy consumption: Exploring home-related practices in Belgium. Energy Res. Soc. Sci. 2018, 39, 19-28.

[86] Webb, D.; Soutar, G.N.; Mazzarol Saldaris, P. Self-determination theory and consumer behavioural change: Evidence fromahousehold energy-saving behaviour study. J. Environ. Psychol. 2013, 35, 59-66.

[87] Pasini, D.; Reda, F.; Häkkinen, T. User engaging practices for energy saving in buildings: Critical review and new enhanced procedure. Energy Build. 2017, 148, 74-88.

[88] Bastida, L.; Cohen, J.J.; Kollmann, A.; Moya, A.; Reichl, J. Exploring the role of ICT on household behavioural energy efficiency to mitigate global warming. Renew. Sustain. Energy Rev. 2019, 103, 455-462.

[89] Hatzl, S.; Brudermann, T.; Reinsberger, K.; Posch, A. Do public programs in 'energy regions' affect citizen attitudes and behavior? Energy Policy 2014, 69, 425-429.

[90] Schleich, J. Energy efficient technology adoption in low-income households in the European Union - What is the evidence? Energy Policy 2019, 125, 196-206.

[91] Liobikiene, G.; Minelgait ' e, A. Energy and resource-saving behaviours in European Union countries: The Campbell paradigm and 'goal framing theory approaches. Sci. Total Environ. 2021, 750, 141745.

[92] Jackson, T. Motivating Sustainable Consumption: A Review of Evidence on Consumer Behavior and Behavioral Change; A Report to the Sustainable Development Research Network; Centre for the Understanding of Sustainable Prosperity: Guild-ford, UK, 2005.

[93] Martiskainen, M. Affecting Consumer Behaviour on Energy Demand; Final Report; EdF Energy: Brighton, UK, 2007.

[94] Stern, P.C. Toward a coherent theory of environmentally significant behavior. J. Soc. Issues 2000, 56, 407-424.

[95] Triandis, H.C. Interpersonal Behavior; Brooks/Cole Publishing Company: Monterey, CA, USA, 1977.

[96] Sagan, A. Podejs'cia do badan' segmentacji rynku. Zesz. Nauk. Akad. Ekon. Krakowie 1995, 457, 19-35.

[97] Słupik, S.; Kos-Łabe dowicz, J.; Trze s siok, J. Report on Findings from Consultations and Online-Survey. Personalised ICT-Tools for the Active Engagement of Consumers towards Sustainable Energy; Report on Findings from Consultations and Online-Survey; Eco-Bot. Project; 2019; Available online: http://eco-bot.eu/ (accessed on 14 June 2021).

[98] Boriah, S.; Chandola, V.; Kumar, V. Similarity measures for categorical data: A comparative evaluation. In Proceedings of the 2008 SIAM International Conference on Data Mining, Atlanta, GA, USA, 24-26 April 2008; Society for Industrial and Applied Mathematics: Philadelphia, PA, USA, 2008; Volume 1, pp. 243-254.

[99] Aldenderfer, M.; Blashfield, R. Cluster Analysis; Sage Publications: Beverly Hills, CA, USA, 1984.

[100] Everitt, B.; Landau, S.; Leese, M.; Stahl, D. Cluster Analysis, 5th ed.; John Wiley \& Sons: Chichester, UK, 2011.

[101] Sokal, R.; Michener, C. A statistical method for evaluating systematic relationships. Sci. Bull. 1958, 38, 1409-1438.

[102] Goodall, D.W. A New Similarity Index Based on Probability. Biometrics 1966, 22, 882-907.

[103] Spark-Jones, K. A statistical interpretation of term specificity and its application in retrieval. J. Doc. 1972, $28,11-21$.

[104] Lin, D. An information-theoretic definition of similarity. In Proceedings of the 15th International Conference on Machine Learning (ICML '98), Madison, WI, USA, 24-27 July 1998; Morgan Kaufmann Publishers Inc.: San Francisco, CA, USA, 1998; pp. 296-304.

[105] Šulc, Z.; Rezankov`á, H. Comparison of Similarity Measures for Categorical Data in Hierarchical Clustering. J. Classif. 2019, $36,58-72$.

[106] Sulc, Z.; Cibulkova, J.; Rezankova, H. Nomclust: Hierarchical Cluster Analysis of Nominal Data, R package version 2.2.1. 2020.

[107] Available online: https://cran.r-project.org/web/packages/nomclust/nomclust.pdf (accessed on 14 June 2021).

[108] Hubert, L.; Arabie, P. Comparing partitions. J. Classif. 1985, 2, 193-218.

[109] Randall, D.M.; Fernandes, M.F. The social desirability response bias in ethics research. J. Bus. Ethics 1991, 10, 805-817. 104. Attari, S.Z.; DeKay, M.L.; Davidson, C.I.; De Bruin, W.B. Public perceptions of energy consumption and savings. Proc. Natl. Acad. Sci. USA 2010, 107, 16054-16059. 